\title{
Histological Changes in Category 2 Animal Byproducts under the Influence of a Ferment Preparation
}

\author{
ALEKSANDR LUKIN, NATALIA NAUMOVA \& KSENIA BITIUTSKIKH
}

\begin{abstract}
The paper deals with the possibility of processing category 2 animal byproducts with a ferment preparation. We chose collagen-rich cattle lips and ears as the category 2 byproducts for our study. The selected samples were processed in the following sequence: fixation, rinsing with running water, densifying the samples, slicing into sections, dying sections, and enclosing the sections under cover glass. The pathohistomorphologic changes found in the control samples significantly differ both before the processing and after the use of the ferment preparation Protepsin, which caused destructive metabolic and hydrolytic processes in the dense connective tissue of the ear and lip framework and led to softening of the muscle parenchyma of the organs.
\end{abstract}

Key words: lips, ears, pathohistomorphologic changes, Protepsin, animal byproducts, ferment.

\section{INTRODUCTION}

The method of producing meat products is closely tied to the peculiarities of the chemical structure and spatial structure of meat proteins. Their ability to change under the influence of water, electrolytes, $\mathrm{pH}$ of the medium, oxidation and deoxidizing agents, heating, ferments, etc. has quite high significance in achieving the necessary functional, processual, and organoleptic properties of the raw materials, as well as the semi-finished and finished meat products. This includes the formation of the coagulative-denaturation structure of minced meat and shrinkage and disintegration of collagen when the products are prepared for consumption. Additional specific technological ferments significantly accelerate the processes and change the properties of the meat (Başkaya et al. 2004).
Despite the relative novelty of the fermentation method of meat processing, it has become widely used in the meat processing industries of a number of countries. Today, it is traditional practice in the US, Canada, England, France, Germany, and more. Adding ferments with proteolytic and collagenase activity into meat and meat systems is especially efficient for the following purposes:

- accelerating post-mortem aging of meat;

- improving the tenderness and richness of meat;

- improving the output of high-quality natural meat products;

- output of meat spreads, meat emulsions, hydrolysates used as protein enrichers in various food products and in dietary therapy;

- sustainable use of meat resources;

- intensification and efficiency of processes of meat product production. 
Improving the quality of meat through fermentation is promising, to a degree, because of the relatively high cost of meat and the small amount of ferments required for tenderization (Neklyudov \& Ivankin 2007).

Endocellular protein-degrading enzymes play a significant role in muscle tissue throughout the life of an animal. These enzymes participate in the destructive metabolism of proteins and supply of plastic materials for biosynthetic reactions, formation and destruction of physiologically-active substances, have a direct influence on the enzymatic structure of a cell through the activation of zymogenes or proteolytic modification of the ferments themselves, etc (Sepehri 2008).

In autolytic transformations of the muscle tissue, the activity of the two main enzyme systems is the most significant. One of these activities is related to the function of movement, while the other catalyzes continuous deterioration of the main structural elements of the muscle fiber, including the actomyosin complex (Bancroft et al. 2013).

These tissue enzyme systems of meat regulate the deterioration of protein substances in both raw meat materials and finished products. It is difficult to overestimate the influence of proteolytic enzymes in animal tissue in the postmortem period. The chemical precursors of the taste and flavor of the meat are accumulated during the biochemical transformations of protein and nitrogenous substances. Among enzymes of the muscle fibers, the most important role during life and the post-mortem period is played by the cathepsin group (Straka \& Malota 2006).

Cathepsines are acid proteinases that manifest maximum activity at $\mathrm{pH}$ 2.0-5.0. They are located in organs and tissue and are localized in lysosomes - endocellular bubbles with a diameter of about $5.5 \mu \mathrm{m}$, limited by a membrane.

Cathepsines are typical proteinases, and cause destruction of high molecular weight proteins. Changes in the properties of proteins are closely related to the activities of cathepsines that are freed from lysosomes during the second period of autolysis and are activated by an acid reaction of the cell environment.

Today, a number of enzymes of endopeptidase action - cathepsines $B_{1}, D, H, L$, $G$ and exopeptidases - cathepsines $A, B_{2}$ and $C$ have been identified in the muscle tissue (Kuzelov et al. 2002).

As a result of the cathepsines' influence on proteins, if the development of autolytic processes is correct, meat becomes tender, rich, and has strong taste and flavor. The nature and the depth of the autolytic changes in meat impact its quality and nutritive value.

In order to accelerate the processes occurring during the autolysis of meat, ferment preparations are being used all the more widely. They have proteolytic and collagenase activity. Ferment preparations are injected into meat systems at various stages of processing depending on the characteristics of the preparation. The best preparations are synergists of endocellular enzymes of meat. It has been established that these preparations should have the following properties to efficiently improve the quality of meat:

- cause changes in the connective tissue by disintegration of the mucopolysaccharide complex;

- contribute to reduced resistance of the connective tissue to heating;

- stimulate hydrolysis of collagen and elastin;

- act in weak acid or neutral medium with maximum activity;

- safe for human consumption. 
The practice of using ferment preparations has shown that not all ferments with high proteolytic activity have the desired effect during meat processing. Some, while intensively catalyzing the hydrolysis of proteins in muscle fibers, weakly influence the proteins of the connective tissue that condition the stiffness of meat. The highest level of ferments activity, the nature of their activators and inhibitors, and their specificity toward destruction of peptide connections during the hydrolysis of animal proteins are of import for meat processing.

\section{MATERIALS AND METHODS}

Protepsin is an animal-based ferment preparation with a complex of acid proteinases. It is intended for use in meat production for processing raw meat products. The ferment composition of the preparation is balanced against the degree of influence on various meat and meat system proteins used in meat production. Protepsin operates in a meat system similar to endocellular enzymes (cathepsines). This preparation is an endocellular enzyme synergist and has additional properties which allow it to impact a wider range of process parameters, as well as protein systems on which endocellular enzymes have no influence (or insignificant impact) (Sadeghinezhad et al. 2015).

Injecting Protepsin into a meat system improves the water-binding capacity and hydration of proteins due to their interaction with the active centers of enzymes. This results in the loosening of the structure of proteins and an increase in the immobilized moisture and the degree of penetration. When using Protepsin, the loss of weight of a meat system at thermal processing reduces.
During the production of meat products, the amount of Protepsin injected is $0.01-0.005 \%$ of the weight of the product.

General characteristics of Protepsin:

- light gray powder;

- standard preparation is issued in three versions with differing proteolytic activity of 50 , 100, and 150 unit/g;

- working activity of the preparation is manifested at 20-45 oc;

- optimal operation temperature of the enzyme in meat systems is 25 oC;

- full inactivation of the ferment complex occurs at 70 oc within 15 minutes;

- the recommended norms for introducing Protepsin are calculated for a system condition of $\mathrm{pH}$ 4.5-6.0.

The study subjects in this paper are:

- category 2 cattle byproducts with a high content of connective tissue (lips and ears);

- ferment preparation Protepsin (standard proteolytic activity is 100 units/g) produced by ZAO Zavod Endokrinnykh Fermentov, Rzhavki settlement, Solnechnogorsky district, Moscow region, in accordance with TU 9219005-42789257-2005, Hygiene Certificate No. 50.16.01.000.M.000638.10.07 dated October 19, 2007.

The selected samples are processed in the following sequence before our study: fixation, rinsing with running water, densifying the samples, slicing into sections, dying sections, and enclosing the sections under cover glass (Picard et al. 1998).

The selected samples are tagged and placed in a formalin solution with $10 \%$ formaldehyde weight and tightly sealed. The solution volume is 10 -fold greater than the volume of the samples. The fixation time at the temperature of $(22 \pm 1){ }^{\circ} \mathrm{C}$ is 24 hours. Lowering the fixation temperature by $10{ }^{\circ} \mathrm{C}$ increases the duration of the fixation twice. 
Samples fixated to a sufficient degree will be evenly densified and have the same appearance both on the external surface and on the newly created section.

The fixated samples are placed in a flask or a glass and, through a glass cone, are flushed with cold running water for 15 minutes (Pearse 1985).

The thoroughly flushed samples are saturated in a 12.5\% gelatin solution for 6 hours, then a $25 \%$ gelatin solution for 12 hours at of $37^{\circ} \mathrm{C}$. Then, the samples are laid out in a Petri dish filled with fresh $25 \%$ gelatin solution, and cooled down quickly in a refrigerator at $(5 \pm 1)$ ${ }^{\circ} \mathrm{C}$. After cooling, the samples are densified in the formaline solution with the formaldehyde weight percent $20 \%$ for 12 hours.

At least three sections of roughly $15 \times 15 \times 4$ $\mathrm{mm}$ are cut from the fixated samples from different areas. 10 to $30 \mu \mathrm{m}$-wide sections are prepared on a freezing microtome (EUROPEAN COMMISION 2002).

The sections are transported from a microtome knife using a thin brush on a crystallizing pan or a Petri dish with faucet water. A glass carrier processed with egg white and glycerin is quickly moved under the non-damaged section quickly. The section is removed from water on the middle of the carrier by extracting it with a preparation needle. The section should not be damaged (Skurikhin \& Tutelyan 1998, Khoshnoodi et al. 2006).

At the first stage, the sections are dyed with aluminous Ehrlich hematoxylin for 3 to 4 minutes and are flushed in water for 2 minutes. In order to remove the excess hematoxylin, the sections are placed in $1 \%$ solution of hydrochloric acid (chloride water) until a pink color appears, then in $1 \%$ solution of ammonia until a blue color appears, and finally flushed with water for 2 minutes. The sections are then dyed with $1 \%$ water-alcohol solution of eosin for 1 minute and rinsed with faucet water. After that, the sections are enclosed under the cover glass (Weigert 1898, Junqueira et al. 1989).

\section{RESULTS AND DISCUSSION}

Histological research of the control samples was performed in their native state and after processing with the ferment preparation with the optimal dose of Protepsin 0.05-0.1\% against the raw material weight. The influence of the Protepsin preparation on the connective tissue of lips and ears of the cattle was evaluated after 1-2.5 hours.

On the histological sections from ear tissue samples, before the processing with the ferment preparation, thickened fiber bunches of the muscle tissue are clearly visible, with insignificant transverse cross-striation at longitudinal sections. Some muscle bundles have cross-sections where nuclei of the muscle cells of elongated form are clearly visible. The muscle bundles have clearly visible eosinophil intensive coloring, which is indicative of the presence of multiple protein fractions, in particular, glycogen, as well as the surface membrane represented by sarcolemma. It is significantly thickened in some places. The nuclei of the muscle fibers are pushed back by myofibrils to the very periphery, and are under the sarcolemma. Sometimes, they lay pairwise or in sequence. Transverse cross-striation of the muscle components in the ears is mild. The structural components of the stroma are represented by close connective tissue with significant number of well-formed fibers, slightly thickened. The cells of the dense connective tissue, as well as muscle tissue, are represented as histiocytes, fibroblasts, and fibrocytes that are primarily elongated fusiform, as well as lymphoid cells. In some layers of the ear muscle parenchyma, there is accumulation 
of multiple fragments consisting of fat tissue that is represented by cellular cavitary lesions of round and subrounded shapes in the preparation (Fig. 1).

In the lip tissue samples, before the histological study, the ratio of muscle bundles that are also represented largely by transverse muscle tissue varies greatly in different places of the organ (Fig. 2).

Nearer to the middle of the lip tissue sample, the muscle tissue has clearly visible sarcoplasm that is intensively dyed with eosin coloring agent. The transverse cross-striation is most visible.

The muscle bundles are more elongated, slightly narrower in diameter than those in the ears, and are located tightly against each other by means of the fibers of the connective tissue. The connective supporting stroma of the organ is represented largely as a non-formed loose connective tissue located between the muscle bundles in a loose, isolated way. Its fibers have clearly visible filamentary geometry, intersperse with each other, and are situated in different directions. The muscle nuclei are more elongated, with clearly visible contours and comparatively small cytoplasm. The myofibril

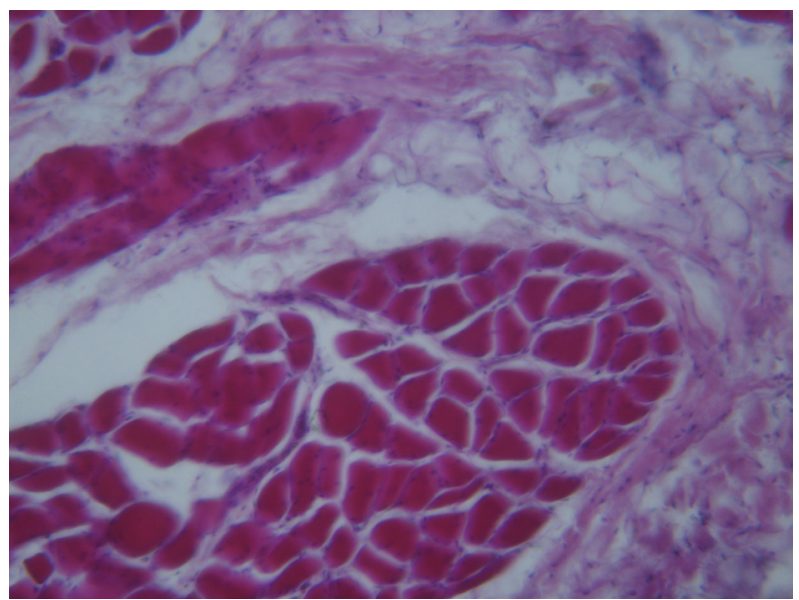

Figure 1. Microstructure of an ear tissue sample before processing with the ferment preparation Protepsin, magn. 400. structure is developed better than in the muscle tissue of ears, with good contractility. In some places, the muscle fibers have diaphragms in the form of "bridges" from connective tissue necks, as well as ligature areas of thinning in the form of shot-shaped contraction. On the edges of lips, nearer to the corner of the mouth, the somatic musculature is developed far worse. As a rule, the muscle bundles are thinned, and contain large amount of intermuscular connective tissue, which is also primarily represented by its loose variety. It contains less fat tissue than the ears.

During the examination of the histological sections after processing with the ferment preparation, there is significant loosening of the connective tissue fibers, both in the ears and lips.

In the lip tissue, insignificant changes of muscle fibers are visible 1 hour after the use of Protepsin: transverse cross-striation gradually becomes less visible, however, the fibers themselves lay tightly against each other. The intermuscular loose connective tissue virtually maintains its structure (Figs. 3, 4 - in 1 hour, hydrolytic changes are insignificant).

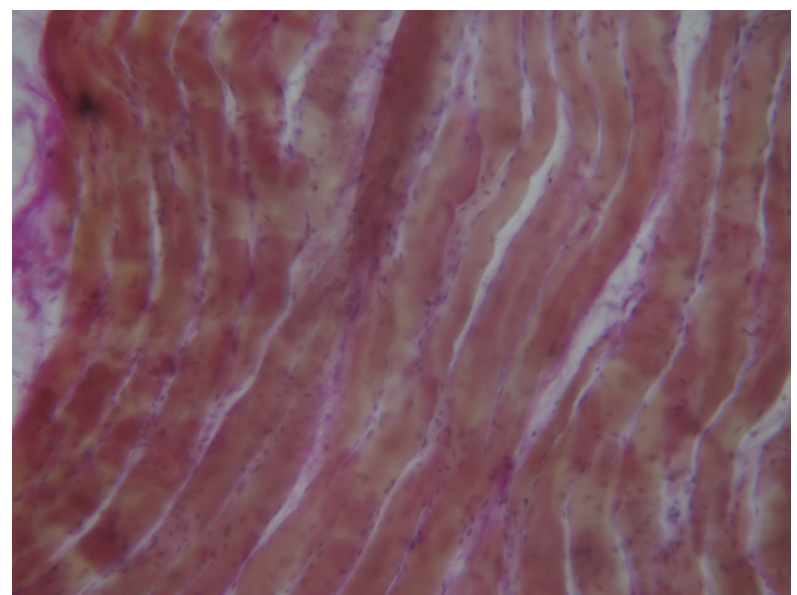

Figure 2. Microstructure of a lip tissue sample before processing with the ferment preparation Protepsin, magn. 200. 
In the ear tissue, destructurization of the muscle fiber is certainly less clearly visible than in the lip tissue, but the connective tissue is still less susceptible to any changes, both quantitatively and qualitatively (Fig. 4).

After 2 hours, the muscle and connectivetissue fibers of the lip tissue processed with Protepsin show some changes in terms of defragmentation, but they are less visible than in the earflap tissue of the experimental groups. Due to their increased plasticity, the muscle fibers are less susceptible to destructurization. Loose connective tissue has smaller changes than those in the ear tissue (Fig. 5).

After 2 hours of processing, it is clear that the muscle fiber structure of the ear tissue sample becomes loose and unclear. It is clearly visible that the fibers have completely lost their transverse cross-striation, have become more swollen, isolated, and defragmented in individual parts, lumps even. Some fragments of the muscle fibers have virtually diluted into amorphous protein substrate masses.

In the tissue fibers, as well as in the neighboring loose connective tissue structures before the experiment, lysis (dilution) has been completed in the nucleus elements. Loose connective tissue has been completely destroyed (Figs. 5 and 6 - after 2 hours, hydrolytic changes are clearly visible - strong loosening of the connective tissue fibers, intermuscular space is significantly enlarged, there is wellformed breast blister with accumulation of protein exudate in some places).

After 2.5 hours of processing, the muscle fibers of the lip and ear samples have lost their transverse cross-striation and clear directionality; the fibers are crimpled, contracted, and defragmented. Loose connective tissue also becomes structureless, and its fibers have less clear contours. The nuclei of both tissues are in karyolysis (Figs. 7 and 8).

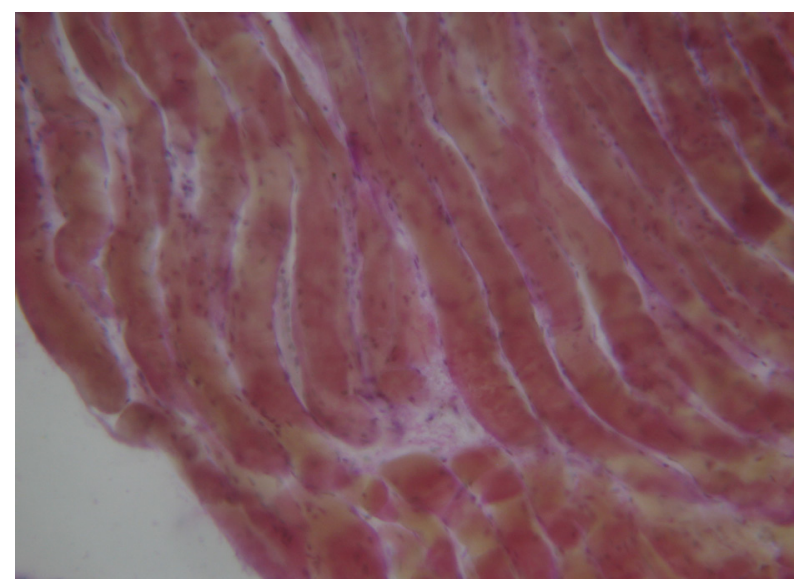

Figure 3. Microstructure of a lip tissue sample after processing with the ferment preparation Protepsin, magn. 200. (after 1 hour).

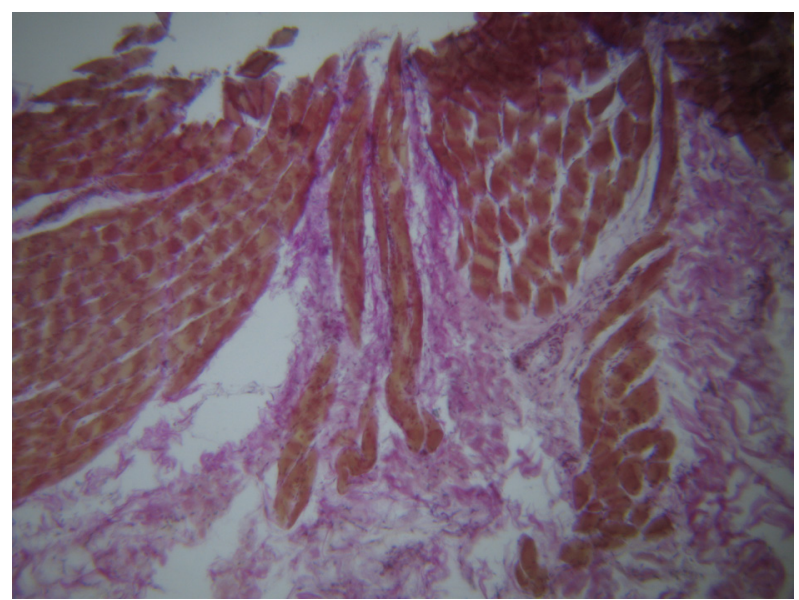

Figure 4. Microstructure of an ear tissue sample after processing with the ferment preparation Protepsin, magn. 400. (after 1 hour).

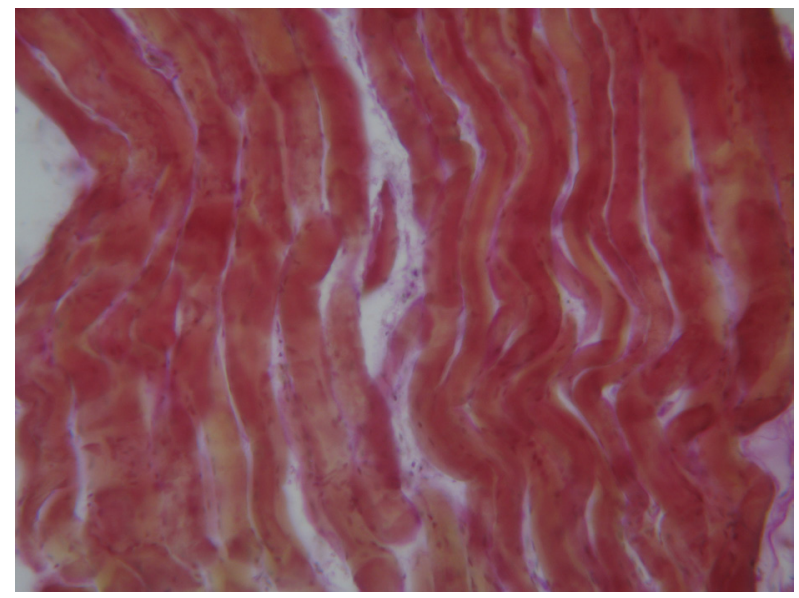

Figure 5. Microstructure of a lip tissue sample after processing with the ferment preparation Protepsin, magn. 200. (after 2 hour). 


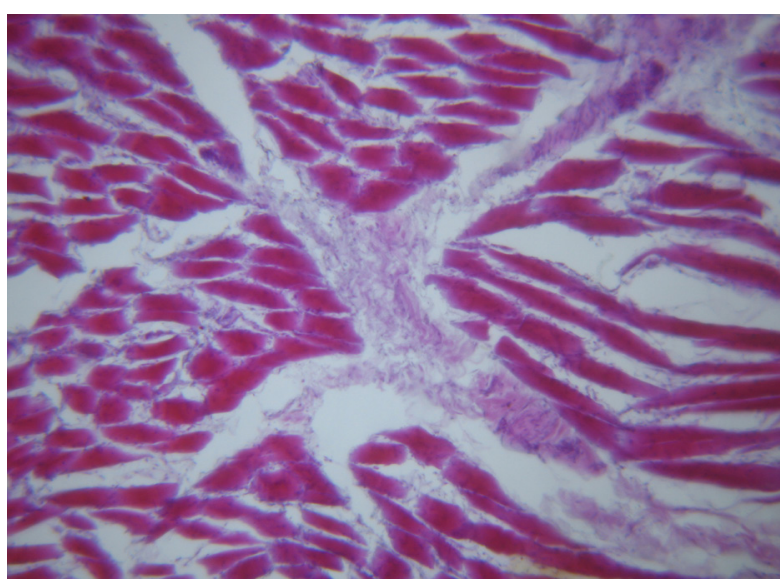

Figure 6. Microstructure of an ear tissue sample after processing with the ferment preparation Protepsin, magn. 400. (after 2 hours).

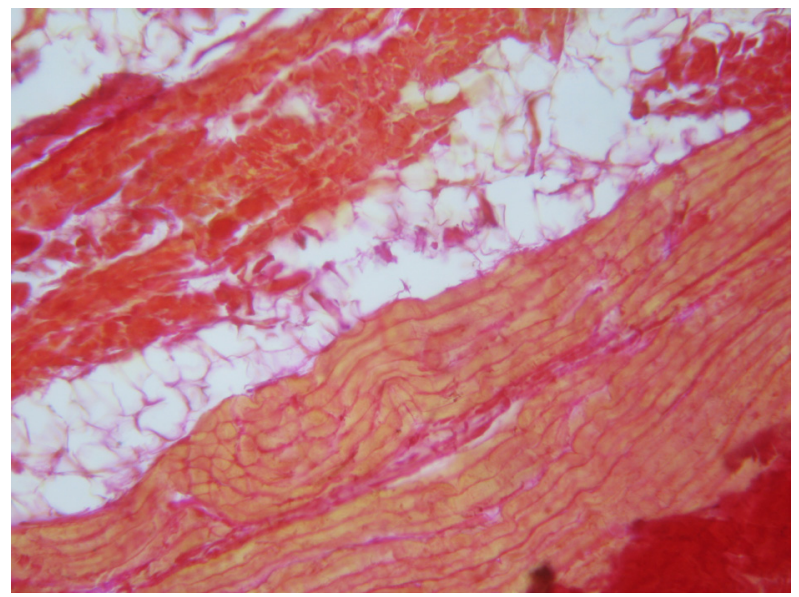

Figure 7. Microstructure of a lip tissue sample after processing with the ferment preparation Protepsin, magn. 400 (after 2.5 hours).

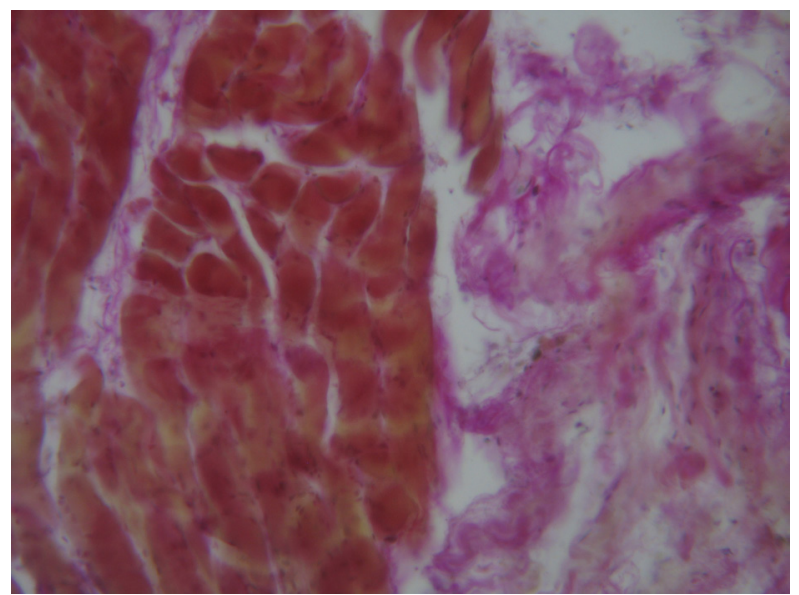

Figure 8. Microstructure of an ear tissue sample after processing with the ferment preparation Protepsin, magn. 200 (after 2.5 hours).
Thus, further processing with Protepsin is not reasonable since the histological examination conducted on processing of lips and ears with the ferment preparation for more than 2.5 hours has not caused further, more clear hydrolytic decomposition on the histological sections of the control samples.

\section{CONCLUSIONS}

Based on the results of the data and analysis of the histological examination, it can be concluded that the pathohistomorphologic changes found in the control samples significantly differ both before the processing and after the use of the ferment preparation Protepsin, causing destructive metabolic and hydrolytic processes in the dense connective tissue of the ear and lip framework, and has led to softening of the muscle parenchyma of the organs. The intermuscular space, after the use of Protepsin, is significantly enlarged, saturated with amorphous substance, and serous inflammation with accumulation of protein exudate is clearly visible in some places. The majority of the nuclei of both connective and muscle tissue are in the state of decomposition (karyorrhexis and karyolysis). The muscle fibers are more isolated and are defragmented in some places. Many of them lose their surface connective membrane, as well as transverse cross-striation.

\section{Acknowledgments}

The work was supported by Act 211 of the Government of the Russian Federation, contract № 02.A03.21.0011.

\section{REFERENCES}

BANCROFT JD, LAYTON C \& SUVARNA SK. 2013. Bancroft's theory and practice of histological techniques, $7^{\text {th }}$ ed., Churchill Livingstone, p. 102-110. 
BAŞKAYA R, KARACA T, SEVINC I, CAKMAK O \& YILDIZ A. 2004. The histological, microbiological and serological quality of ground beef marketed in istanbul. Van Yuzuncu Yil University, Faculty of Veterinary Medicine 15: 41-46.

EUROPEAN COMMISION. Commission Decision 2002/657/EC of 12 August 2002 implementing Council Directive 96/23/ EC concerning the performance of analytical methods and the interpretation of results. OJEC L 2002(221): 8-36.

JUNQUEIRA LC, CARNEINO J \& KELLEY RO. 1989. Basic histology, $6^{\text {th }}$ ed., New York Prentice Hall International.

KHOSHNOODI J, CARTAILLER JP, ALVARES K, VEIS A \& HUDSON GB. 2006. Molecular Recognition in the Assembly of Collagens: Terminal Noncollagenous Domains Are Key Recognition Modules in the Formation of Triple Helical Protomers. JBC 281(50): 38117-38121.

KUZELOV A, VASILEV K \& VELKOVA K. 2002. Influence of microbial enzyme preparation upon structural and mechanical properties of meat raw materials from big ruminants. FTI 4: 13-14.

NEKLYUDOV AD \& IVANKIN AN. 2007 Collagen: production, properties and application. Moscow: Publishing house MGUL, p. 336.

PEARSE AGE. 1985. Histochemical: Theoretical and applied. Churchill, London, $145 \mathrm{p}$.

PICARD B, DURIS MP \& JURIE C. 1998. Classification of bovine muscle fibres by different histochemical techniques. Histochem 30: 473-479.

SADEGHINEZHAD J, HAJIMOHAMMADI B, IZADI F, YARMAHMOUDI F \& LATORRE R. 2015. Evaluation of the morphologic method for the detection of animal and herbal content in minced meat. Czech J Food Sci 33: 564-569.

SEPEHRI ES. 2008. Histological methods evaluation for detection of adulteration of raw meat products supplied in Tehran. University of Tehran, Tehran, Iran.

SKURIKHIN IM \& TUTELYAN VA. 1998. A guide to the methods of analyzing food quality and safety. Moscow, Brandes, Medicine, p. 23-37.

STRAKA I \& MALOTA L. 2006. Chemické vyšetření masa: klasické laboratorní metody (Chemical determination of meat: classic laboratory methods). Tábor, Czech Republic: OSSIS, 94 p. ISBN-80-86659-09-7.

WEIGERT C. 1898. Study on a method for dyeing elastic fibers. ZL Pathol 9: 289-292.

\section{How to cite}

LUKIN A, NAUMOVA N \& BITIUTSKIKH K. 2020. Histological Changes in Category 2 Animal Byproducts under the Influence of a Ferment Preparation. An Acad Bras Cienc 92: e20180894. DOI 10.1590/00013765202020180894.

Manuscript received on August 30, 2018; accepted for publication on November 30, 2018

\section{ALEKSANDR LUKIN}

https://orcid.org/0000-0003-4753-3210

\section{NATALIA NAUMOVA}

https://orcid.org/0000-0003-0586-6359

\section{KSENIA BITIUTSKIKH}

https://orcid.org/0000-0002-7361-7322

Federal State Autonomous Educational Institution of Higher Education, South Ural State University/National Research University, 76, Lenin Prospekt, 454080 Chely abinsk, Russia

Correspondence to: Aleksandr Lukin

E-mail: lukin3415@gmail.com

\section{Author contributions}

Aleksandr Lukin developed this study, processed the data, performed the analysis, interpreted the results and worked on the manuscript. Natalia Naumova conceived of the presented idea, and supervised the findings of this work. Ksenia Bitiutskikh contributed to sample preparation, was responsible for reviewing the final manuscript.

\section{(cc) BY}

